\title{
Evening Primrose Oil Attenuates Certain Radiation Induced Functional and structural Disorders in Female Rats.
}

\author{
Fatma, L.R. and Rezk R. G.
}

\author{
Radiation Biology, Department . NCRRT. \\ Radiation Health Research Department NCRRT.
}

\begin{abstract}
The aim of the present study was to evaluate the modulator role of evening primrose oil (EPO) on the radiation induced changes in certain biochemical and histological abnormalities.

Female rats were exposed to 5 Gy whole body $\gamma$-irradiation delivered as single dose. EPO was orally administrated to rats $(9 \mathrm{ml} / 100 \mathrm{~g} \mathrm{b.wt}) 7$ days before irradiation exposure. Animals were sacrificed 1 day (oestrus stage), 6 days (one estrus cycle) and 12 days (two estrus cycle) after irradiation. The results obtained revealed that treatment with EPO diminished the increase in total cholesterol, urea and creatinine levels in plasma in comparison with the levels recorded in the plasma of irradiated rats. Significant amelioration of the radiation induced changes in RBC's WBC's count and the haemoglobin concentration, calcium level, FSH and LH hormones were also recorded in the plasma of EPO treated and irradiated rats. Histological observations of photomicrograph of kidney and ovary sections showed that irsaoiaun resulted in irradiation induced ruptured, dilated, haemorrhage glomerulei dissolution of the majority of primary follicles, and atrophy in ovary size. All these changes were obviously improved in animals supplied with EPO.

It could be concluded that EPO could be useful adjunct for maintaining the integrity of biochemical functions and restoring the original histological architecture of kidney and ovary after irradiation.
\end{abstract}

\section{Introduction}

Evening Primrose oil derived from plant seeds was shown to possess antidiabetic and anti-inflammatory properties (Garland et al., 1997 and Schalin-Karrila et al., 1987). The oil contains the essential fatty acids Gamma linolenic acid (GLA) and linoleic acid (LA) vital to body health (Barcelli et al., 1990). GLA is a precurser of prostaglandins a group of highly reactive molecules which plays a role in regulation of growth and reproduction (Horrobin, 1983), as well as in treatment of breast pain, tenderness and fluid retention occurred in premenstrulation.

Radiation interacts with matter by direct and indirect processess to form ion pairs, some of which may be free radicals that lead to molecular damage translated to biochemical damage that may be then amplified and expressed as biological injury (Cockerham et al., 1994).

One of the systems most sensitive to irradiation is the hematopoietic system which is characterized by a depression in the peripheral blood levels after irradiation (Monroy, 1987).

The kidney was reported to be relatively radiosensitive compared to other abdominal organs. Pathophysiological and histopathological changes are dose and time dependent.

Pathologic changes in endothelial cells of renal microvasculature appears soon after exposure to radiation and later tubule and glomeruli degeneration are observed (Mettler \& Moseley, 1985 and Yeas, 1992).

Radiosensitivity of the ova depends 
on the maturity of the follicle. Irradiation of radiosensitive mature and intermediate follicles results in periods of temporary sterility followed by fertility due to maturation of surviving immature follicles (Robertson, 1989). Exposure to radiation reduces the formation of ovarian steriod hormones (Littly et al., 1991). Exposure to large radiation doses produce premature menopause (Walden and Farzaneh, 1990) and elevate gonadotropin levels (FSH and LH) (Wallace et al., 1989).

Due to the vital importance of EPO, the present work was undertaken to evaluate its role in minimizing radiation induced changes in hematopoietic system, the blood levels of total cholesterol, calcium, kidney functions, the blood levels of FSH and LH. Histological examination of kidney and ovary tissues were performed in parallel.

\section{Material And Methods}

Female albino rats weighing about $(120-170 \mathrm{~g})$ were obtained from the animal farm of the Egyptian Organization for Vaccine and Biological Products. The animals were housed in cages and maintained under standard conditions of ventilation, temperature, and humidity. Food and water were available adlib. The animals were examined daily using the vaginal smear technique to determine the suitable estrus cycle according to Mahesh and Brann (1992).

Animals were categorized into four equal groups (each of 18 rats) as follows:

Group 1: Control; Group 2: Evening Primrose oil; Group 3: Irradiated ; Group 4: Evening Primeose Oil and irradiated.

Irradiation was carried out using a ${ }^{137}$ Cs source (Gamma cell-40) at National Center for Radiation Research and Technology (NCRRT, Cairo, Egypt) with a dose rate of $1 \mathrm{~Gy} / 1.2 \mathrm{~min}$ at the time of experiment. Rats were exposed to 5 Gy whole body gamma irradiation delivered as a single dose. The rats were irradiated at proestrus stage (for measuring FSH and LH). The blood was collected in ostrus stage one day, 6 days and 12 days after irradiation.

EPO after dilution in corn oil before use $(9 \mathrm{ml} / 100 \mathrm{~g}$ body weight) was orally administered to rats by means of a stomach needle for 7 consecutive days before irradiation exposure.

EPO was purchased from Glaxowellecome (Egypt). Animals were fasted over neight and five rats were sacrificed from each group $24 \mathrm{hrs}, 6$ days and 12 days after irradiation.

Blood samples were collected into dry EDTA tubes and plasma separated by centrifugation. Kidney and ovary were removed for histological analysis.

\section{1- Biochemical analysis:}

Kidney functions were evaluated in separated sera using commercial kits for colourimetric measurements of creatinine and urea nitrogen (Henry, 1974). Blood samples were collected in dry EDTA tubes used for the investigation of erythrocytic counts (RBC's), total leucocytic count (WBC's) and estimation of haemoglobin concentration according to Dacie and Lawis (1993).

Serum total cholesterol content was determined according to the method of Allain et al., (1974). Calcium level was evaluated according to Stem and Lewis (1957).

FSH and LH were assayed using radioimmunoassay technique (Radbard, 1974 and Garza et al., 1975).

\section{2- Histological analysis:}

For the histological preparations, serial paraffin sections of the kidney and ovary were prepared. The kidney and ovary were immediately excised, fixed in buffered formol, processed routinely for paraffin embedding and sectioned at $6 \mu \mathrm{m}$. All sections were simultaneously stained with haematoxylin, and eosin (HE) in an automatic slide stainer and mounted with Canda balsam. Sections were examined by Zeiss light microscope to detect the histopathological changes.

The students T-test (Senedecor and Cochran, 1978) was applied for the 
statistical analysis of the results. The results were considered significant at $\mathrm{P}<0.05$.

\section{Results}

\section{1- Biochemical Analysis:}

Data on experimental animals showed that normal healthy rats treated with $9 \mathrm{ml}$ $\mathrm{EPO} / 100 \mathrm{~g}$ body weight did not show any obvious harmful deleterious side effects but showed normal RBC's, WBC's count and haemoglobin concentration (Table 1). Normal total cholesterol, calcium (Table 2). Normal levels of urea and creatinine (table 3 ) and normal levels of FSH and $\mathrm{LH}$ contents in serum (table 4).

Whole body gamma irradiation of rats exposed to 5 Gy single dose resulted in significant drop in RBC's, WBC's count and haemoglobin concentration (table 1), significant increase in the level of total cholesterol, significant decrease in calcium level (table 2). A significant increase in plasma urea nitrogen and creatinine levels (table 3). A significant elevation in serum FSH and LH was recorded in all time intervals after irradiation as compared with control values (table 4).

However, treatment of irradiated rats with $9 \mathrm{ml} / 100 \mathrm{~g}$ body weight of EPO had significantly modulated the radiation induced decrease in RBC's, WBC's count and haemoglobin concentration (table 1). EPO ameliorated and reduced significantly the induced changes recorded in the above investigated parameters (table 2, 3 and 4).

\section{2- Histological observations:}

Kidney:- sections of control rats showed a normal renal cortex with normal renal corpuscles and the surrounding proximal and distal convulated tubules. This section includes both vascular pole and the tubular pole of the renal corpuscle. At the vascular pole, normal lumen of an arteriole (a) and the macula densa (md) in the wall of the distal tubule could be distinguished. Some lacis cells could also be seen between the arteriole and the macula densa. At the tubular pole, the capsular space is continous with the lumen of the proximal convulated tubule $(\mathrm{Pt})$ and normal proximal convulated tubule $(\mathrm{PCt})$. In contrast, cross sections of the distal convulated tubule (dct) exhibited more nuclei in the poler staining walls and lack a distinict striated border (Fig.1 ). Kidney section of rats treated with EPO showed normal renal cortex with normal corpuscle and the surrounding proximal and distal convulated tubules (Fig. 2).

Whole body exposure of rats to $5 \mathrm{~Gy}$ gamma irradiation delivered as single dose, resulted in loss of normal renal cortex with loss in corpuscle structure, widened, dilated and rupture proximal and distal convulated tubules (Fig.3) After $6 \& 12$ days radiation showed extremely widening and dilation, ill-defined structure of glomerulai, haemorrhage, high content of inflammatory cells and fibroblasts in the glomerulai and surrounding it, ill defined structure of proximal and distal convulated tubules (Fig. $4 \& 5)$.

Treatment of rats with Evening Primrose Oil led to improvement of renal cortex and preserved renal corpuscles architecture and the surrounding proximal and distal convulated tubules. The changes recorded after 24 hrs, 6 and 12 days post irradiation were less pronounced as compared to those recorded with irradiated rats (Fig. $6,7 \& 8$ ).

Ovary sections of control rats showed normal developing ovarian follicles. Primordial follicles, with one layer of flattened follicular cells. Normal corpus luteum with granulosa cells and theca cells (fig.9)

Ovary:- section of rats treated with Evening Primrose Oil showed normal developing ovarian follicles. Mature corpus luteum with granulosa cells and theca cells (fig. 10).

The effect of irradiation on ovarian tissue is clearly shown in Fig.11 in the from of primary and secondary follicles with abnormal shape and dissolution of the majority of the follicles. Absence of mature follicles. Fibroblasts filled the section. These features were after $24 \mathrm{hrs}$ post irradiation.

After 6 and 12 days post irradiation, the section showed extremely dissolution and ill-defined shaped follicles, absence of immature follicles, whereas high content of fibroblasts filled the sections (Fig. $12 \& 13$ ). 
Fatma, L.R. \& and Rezk R. G.

A significant protection was afforded when animals were supplied with EPO pre irradiation exposure. The ovary sections showed well defined germinal epithelium, Tunica albuginea, different stages of follicles formation as perimordial follicles, primary follicles and mature corpus luteum with granulosa cells, well defined thecal cells. These feature were seen after $24 \mathrm{hrs}$ after irradiation (Fig. 14). While after 6 and 12 days regeneration of primordial, primary and secondary follicles with gronulosa cells and regeneration of normal thecal cells (Fig. 15 \& 16).were seen.

Table (1): Haematological values of female rats at various time entervals after whole body gamma irradiation (5 Gy) and / or Evening Primrose treatment.

\begin{tabular}{|c|c|c|c|c|}
\hline Group & days & Haemoglobin g/dI & $\begin{array}{c}\text { RBC's } \\
\text { count } \times 10^{6} / \mathrm{ml}\end{array}$ & $\begin{array}{c}\text { WBC's } \\
\text { count } \times 10^{3} / \mathrm{ml}\end{array}$ \\
\hline $\mathrm{C}$ & & $\begin{array}{c}\text { Mean } \pm \text { SE } \\
14.97 \pm 0.002\end{array}$ & $5.45 \pm 0.009$ & $5.99 \pm 0.008$ \\
\hline $\mathbf{R}$ & $\begin{array}{c}1 \\
6 \\
12 \\
\end{array}$ & $\begin{array}{l}12.02 \pm 0.007^{*} \\
10.45 \pm 0.126^{*} \\
11.25 \pm 0.003^{*}\end{array}$ & $\begin{array}{l}4.42 \pm 0.302^{*} \\
3.75 \pm 0.008^{*} \\
3.55 \pm 0.105^{*}\end{array}$ & $\begin{array}{l}3.90 \pm 0.130^{*} \\
3.28 \pm 0.142^{*} \\
4.40 \pm 0.005^{*}\end{array}$ \\
\hline EPO & $\begin{array}{c}1 \\
6 \\
12\end{array}$ & $\begin{array}{l}14.80 \pm 0.006 \\
14.89 \pm 0.005 \\
14.50 \pm 0.109\end{array}$ & $\begin{array}{l}5.45 \pm 0.006 \\
5.33 \pm 0.005 \\
5.40 \pm 0.208\end{array}$ & $\begin{array}{c}5.900 \pm 0.122 \\
5.88 \pm 0.185 \\
5.98 \pm 0.125\end{array}$ \\
\hline EPO+R & $\begin{array}{c}1 \\
6 \\
12\end{array}$ & $\begin{array}{c}12.45 \pm 0.13^{* \mathrm{a}} \\
12.80 \pm 0.005^{* *} \\
12.65 \pm 0.004^{* \mathrm{a}}\end{array}$ & $\begin{array}{l}4.49 \pm 0.00 *^{*} \\
4.99 \pm 0.29 *^{* a} \\
4.45 \pm 0.007 *^{\mathrm{a}}\end{array}$ & $\begin{array}{l}5.16 \pm 0.172^{\mathrm{a}} \\
5.31 \pm 0.004^{\mathrm{a}} \\
5.46 \pm 0.291^{\mathrm{a}}\end{array}$ \\
\hline
\end{tabular}

Each value represents mean of 5 observations \pm SE

(*) mean significantly different from control group $\mathrm{P} \leq 0.05$

(a) mean significantly different from irradiated group $\mathrm{P} \leq 0.05$

Table (2): Serum cholesterol and calcium levels in blood of female rats at various time intervales after whole body gamma irradiation (5 Gy) and / or EPO treatment.

\begin{tabular}{|c|c|c|c|}
\hline Group & days & Total cholesterol mg/ml & Calcium mg/ml \\
\hline \multirow{2}{*}{$\mathrm{C}$} & & Mean $\pm \mathrm{SE}$ & \\
& & $58.72 \pm 0.008$ & $11.60 \pm 0.010$ \\
\hline \multirow{3}{*}{$\mathbf{R}$} & $\mathbf{1}$ & $91.91 \pm 0.0003^{*}$ & $8.50 \pm 0.114^{*}$ \\
& $\mathbf{6}$ & $108.40 \pm 0.009^{*}$ & $8.02 \pm 0.12^{*}$ \\
& $\mathbf{1 2}$ & $89.46 \pm 00.006^{*}$ & $7.16 \pm 0.004^{*}$ \\
\hline \multirow{2}{*}{ EPo } & $\mathbf{1}$ & $58.75 \pm 0.007$ & $11.59 \pm 0.007$ \\
& $\mathbf{6}$ & $58.87 \pm 0.355$ & $11.65 \pm 0.123$ \\
& $\mathbf{1 2}$ & $59.07 \pm 0.491$ & $11.51 \pm 0.007$ \\
\hline \multirow{3}{*}{ EPO+R } & $\mathbf{1}$ & $73.55 \pm 0.107^{\mathrm{a}}$ & $10.60 \pm 0.00 *^{\mathrm{a}}$ \\
& $\mathbf{6}$ & $76.08 \pm 0.000 *^{\mathrm{a}}$ & $10.85 \pm 0.00 *^{\mathrm{a}}$ \\
& $\mathbf{1 2}$ & $74.46 \pm 0.116^{* \mathrm{a}}$ & $10.50 \pm 0.00 *^{\mathrm{a}}$ \\
\hline
\end{tabular}

Each value represents mean \pm SE of 5 observations + SE.

(*) mean significantly different from control group at $\mathrm{P} \leq 0.05$

(a) mean significantly different from irradiated group $\mathrm{P} \leq 0.05$ 
Table (3): Serum Urea and Creatinine levels in blood of female rats at various time intervals after whole body gamma irradiation (5 Gy) and / or EPO treatment.

\begin{tabular}{|c|c|c|c|}
\hline Groups & days & Serum Urea $\mathrm{mg} / \mathrm{dl}$ & Serum Creatinine mg/dl \\
\hline $\mathrm{C}$ & & $16.42 \pm 0.007$ & $0.86 \pm 0.05$ \\
\hline & $\mathbf{1}$ & $40.90 \pm 0.264^{*}$ & $1.25 \pm 0.005^{*}$ \\
$\mathbf{R}$ & $\mathbf{6}$ & $48.70 \pm 0.181^{*}$ & $1.40 \pm 0.007^{*}$ \\
& $\mathbf{1 2}$ & $38.11 \pm 0.259^{*}$ & $1.07 \pm 0.001^{*}$ \\
\hline & $\mathbf{1}$ & $17.51 \pm 0.11^{*}$ & $0.92 \pm 0.001$ \\
EPO & $\mathbf{6}$ & $17.01 \pm 0.13^{*}$ & $0.99 \pm 0.004$ \\
& $\mathbf{1 2}$ & $17.74 \pm 0.003^{*}$ & $1.02 \pm 0.002$ \\
\hline & $\mathbf{1}$ & $30.05 \pm 0.005^{*^{\mathrm{a}}}$ & $1.19 \pm 0.002^{*}$ \\
EPO+R & $\mathbf{6}$ & $25.31 \pm 0.113^{\mathrm{a}}$ & $1.12 \pm 0.003^{\mathrm{a}}$ \\
& $\mathbf{1 2}$ & $20.01 \pm 0.004^{\mathrm{a}}$ & $1.04 \pm 0.007^{\mathrm{a}}$ \\
\hline
\end{tabular}

Table (4): The concentration of follicle stimulating hormone (FSH) and luteinizing hormone $(\mathrm{LH})$ in the sera of female rats at various time intervals after whole body gamma irradiation and / or Evening Primrose oil treatment

\begin{tabular}{|c|c|c|c|}
\hline Groups & days & FSH $\mathrm{ml} \mu / \mathrm{ml}$ & LH $\mathbf{~ m l ~} \mathbf{\mu} / \mathbf{m l}$ \\
\hline C & & $6.25 \pm 0.005$ & $7.086 \pm 0.0005$ \\
\hline & $\mathbf{1}$ & $9.33 \pm 0.008^{*}$ & $8.42 \pm 0.004^{*}$ \\
$\mathbf{R}$ & $\mathbf{6}$ & $11.43 \pm 0.139^{*}$ & $8.99 \pm 0.0009^{*}$ \\
& $\mathbf{1 2}$ & $18.01 \pm 0.0001^{*}$ & $11.59 \pm 0.007^{*}$ \\
\hline & $\mathbf{1}$ & $6.07 \pm 0.001^{*}$ & $7.91 \pm 0.0001^{*}$ \\
EPO & $\mathbf{6}$ & $7.20 \pm 0.007^{*}$ & $7.21 \pm 0.007$ \\
& $\mathbf{1 2}$ & $7.70 \pm 0.001^{*}$ & $6.75 \pm 0.007^{*}$ \\
\hline & $\mathbf{1}$ & $8.15 \pm 0.003^{*^{\mathrm{a}}}$ & $8.27 \pm 0.003^{* \mathrm{a}}$ \\
$\mathbf{E P O}+\mathbf{R}$ & $\mathbf{6}$ & $9.35 \pm 0.112^{*^{\mathrm{a}}}$ & $8.39 \pm 0.007^{* \mathrm{a}}$ \\
& $\mathbf{1 2}$ & $10.53 \pm 0.177^{\mathrm{a}}$ & $9.22 \pm 0.006^{* \mathrm{a}}$ \\
\hline
\end{tabular}

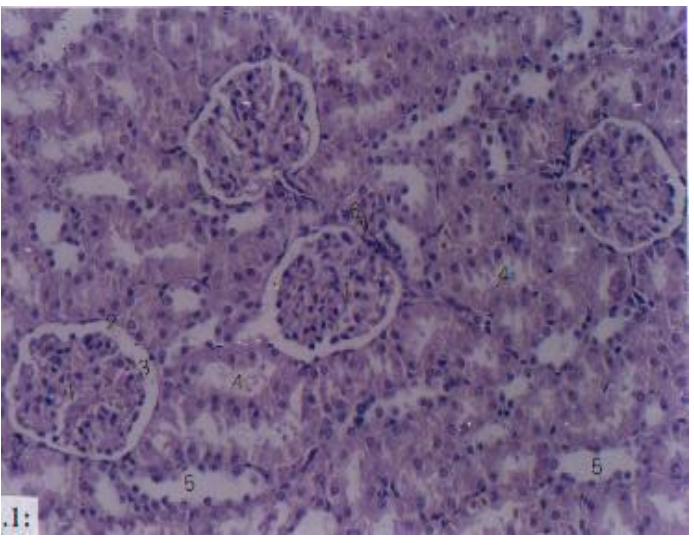

Fig.1: Photomicrograph of a section in the kidney of control rat showing normal renal cortex architecture with normal 1. glomerulus 2. glomular capsule 3 . urinary space between the glomerulus and the capsule .4. proximal convulated tubules are dark staining.5. distal convulated tubules are lighter staining .6. macula densa (X.200)

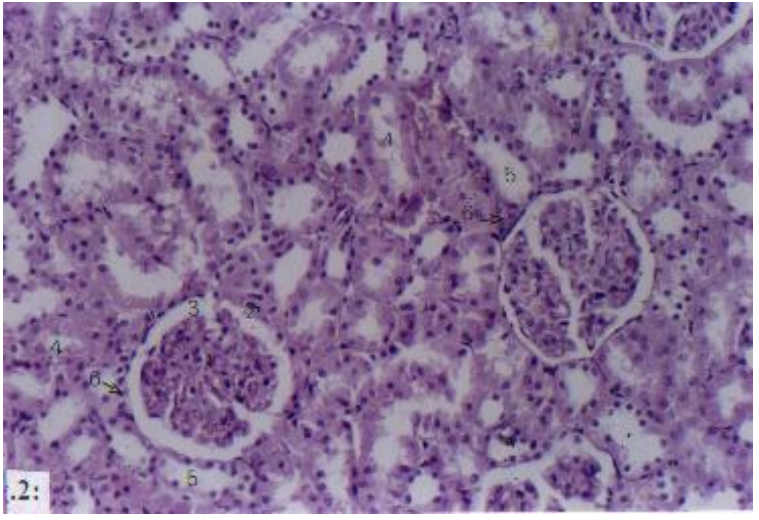

Fig.2: Photomicrograph of a section in the kidney of Evening Primrose Oil treated rat showing normal renal cortex architecture with normal. 1. glomerulus. 2. glomular capsule 3 . urinary space between the glomerulus and the capsule. 4. proximal convulated tubules are dark satining and 5. normal distal convulated tubules are lighter staining.6. macula densa. (X200). 
Fatma, L.R. \& and Rezk R. G.

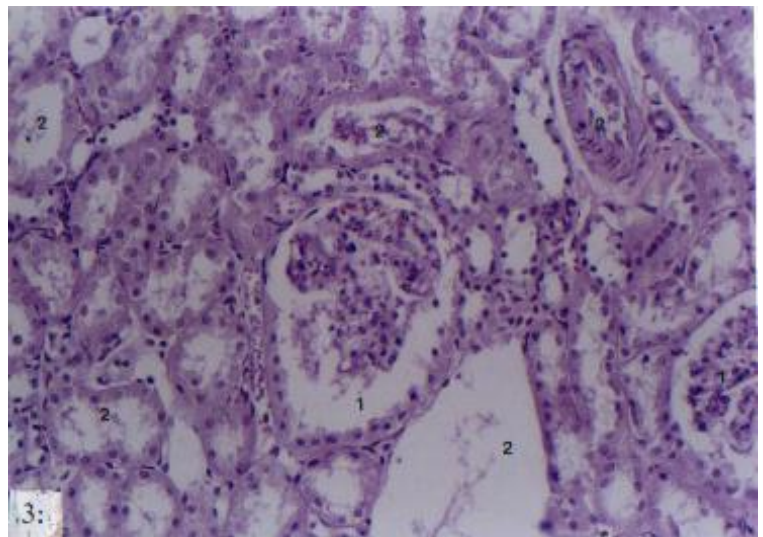

Fig.3: Photomicrograph of a section in the kidney of rats $24 \mathrm{hrs}$ after irradiation showing loss of normal renal cortex, loss renal corpuscle structure. 1. Widened, dilated glomerulus .2. ruptured and dilated proximal and distal convulated tubules (X 200).

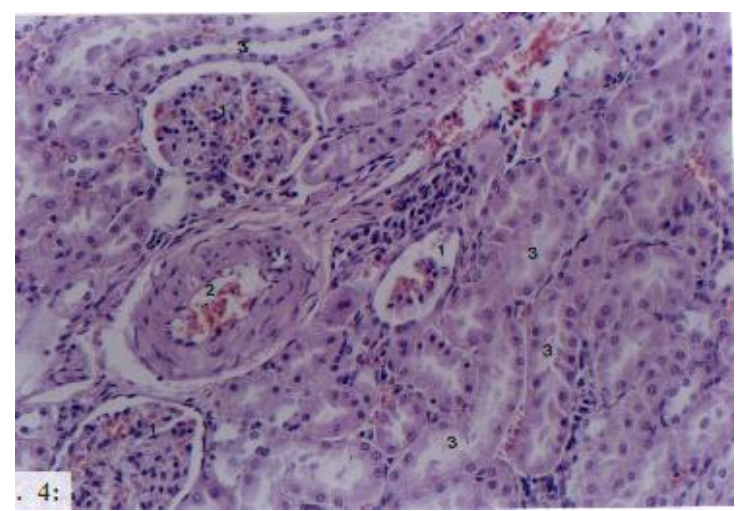

Fig. 4: Photomicrograph of a section in the kidney 6 days after irradiation showing 1. Illdefined glomerulai.2. glomerulus sclerosis.3. Extremely widened, dilated and ill-defined proximal \& distal convulated tubules (X 200).

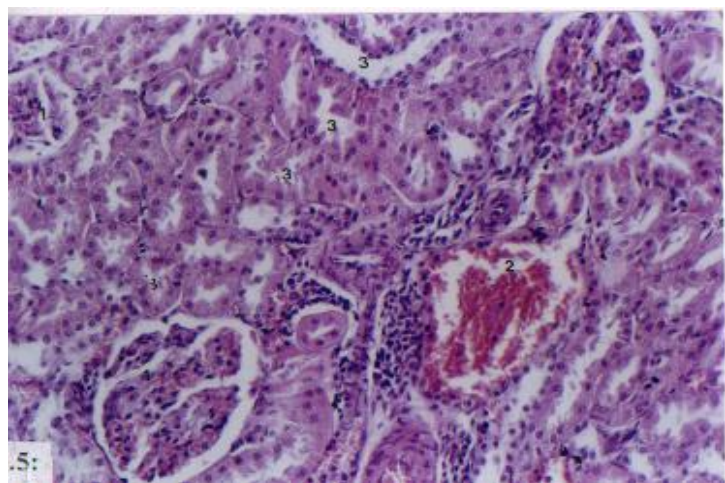

Fig.5: Photomicrograph of a section in the kidney 12 days after irradiation showing 1 . illdefined glomerulai. 2. high content of inflammatory cells and fibroblasts, haemorrhage in the glomerulai and surrounding it. 3. illdefined structure of proximal and distal convulated tubules.

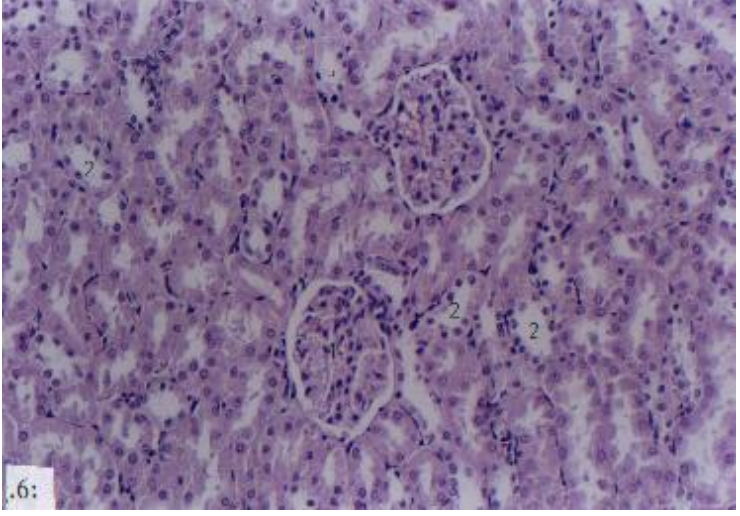

Fig.6: Photomicrograph of a section in the kidney of Evening Primrose Oil treated rat $24 \mathrm{hrs}$ after irradiation showing normal renal cortex with 1 . well-defined glomerulus structure. 2. regeneration of distal and proximal convulated tubules (X 200).

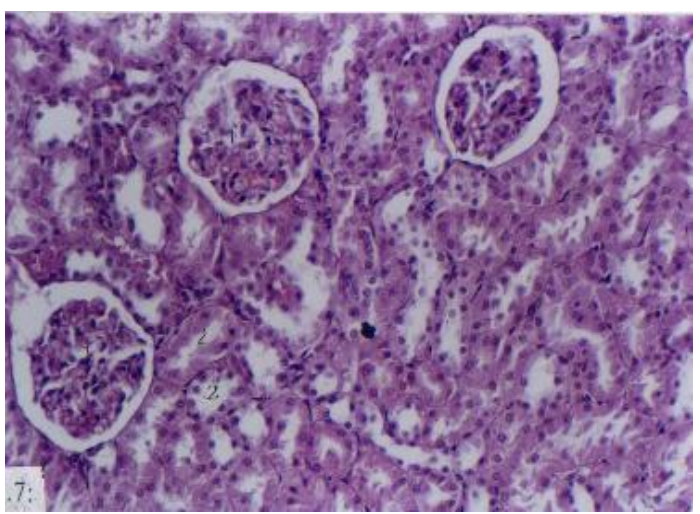

Fig.7: Photomicrograph of a section in the kidney of Evening Primrose Oil treated rat 6 days post irradiation showing 1 . improved glomerulai structure 2. regeneration of distal and proximal convulated tubules (X 200).

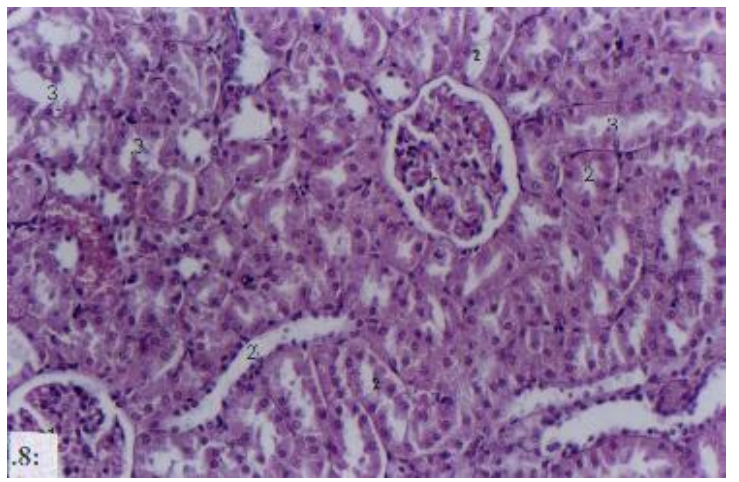

Fig.8: Photomicrograph of a section in the kidney of Evening Primrose Oil treated rat 12 days post irradiation showing 1. well-defined structure of glomerulai. 2. Some proximal and distal convulated tubules were regenerated and. 3. Some still ill-defined structure. 


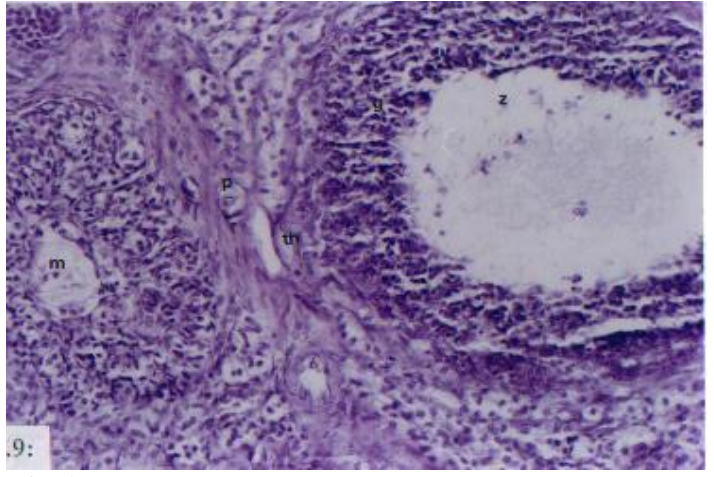

Fig.9: Photomicrograph of a section in the ovary of a control rat showing normal primordial follicles with flattened follicular cells (P). 2. normal ripening follicle with stratified follicular epithelium (granulosa) (g), and nature corpus luteum (m). zona pellucida (z) and developing theca (th).

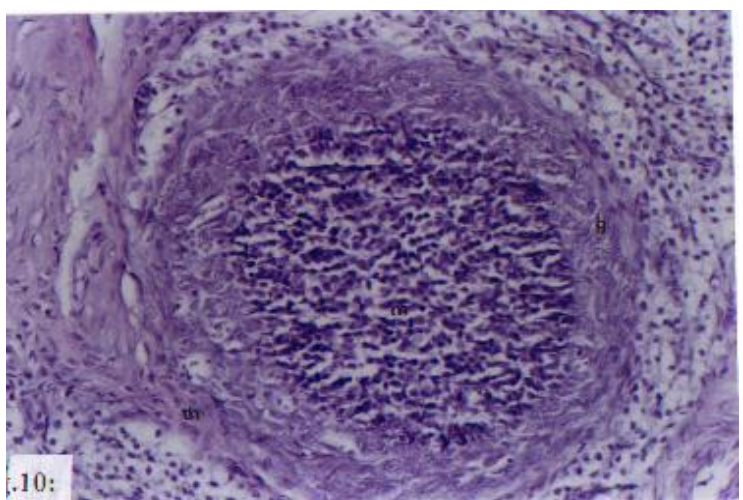

Fig.10: Photomicrograph of a section in the ovary of Evening Primrose Oil treated rats showing normal developing ovarian follicle with mature corpus luteum (m), normal granulosa cells (g) and theca cells (th) (X200)

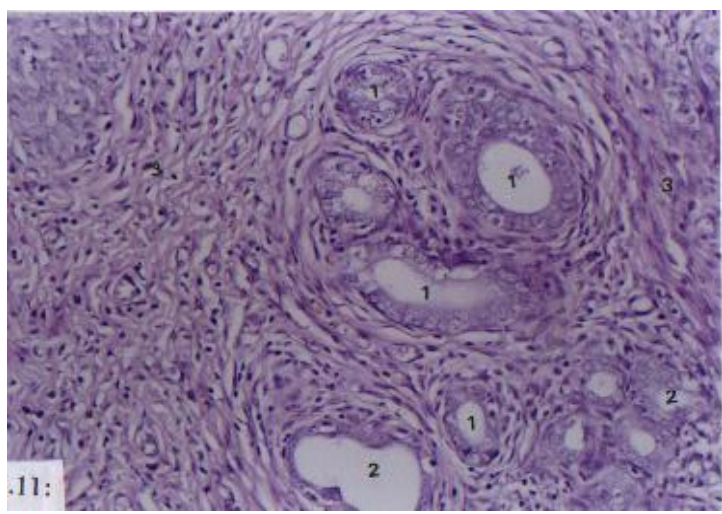

Fig.11: Photomicrograph of a section in the ovary of rats $24 \mathrm{hrs}$ after irradiation showing 1. abnormal shaped primary and secondary follicles .2. dissolution of follicles . 3. high content of fibroblasts filled the section (X200).

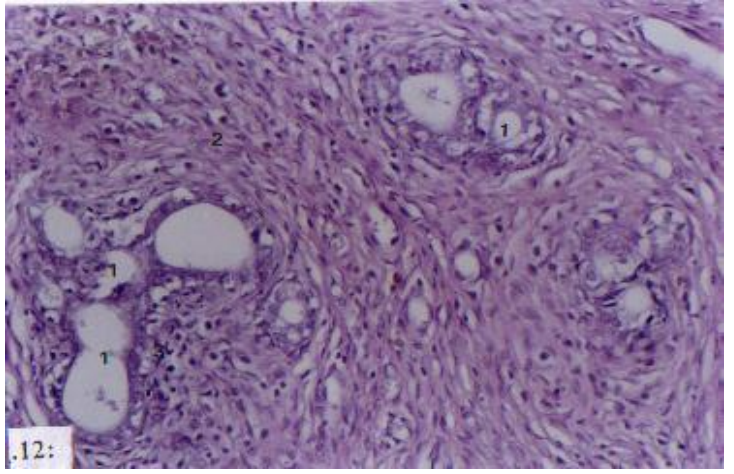

Fig.12: Photomicrograph of a section in the ovary of rats 6 days post irradiation showing 1 . dissolution of the ovarian follicles. 2. high content of fibroblasts filled the section .3. inflammatory cells around the dissolved follicles (X200).

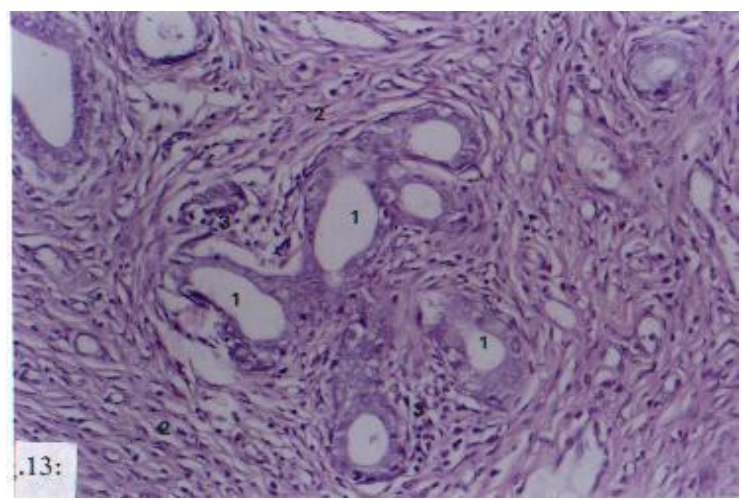

Fig.13: Photomicrograph of a section in the ovary of rat 12 days post irradiation showing 1 . dissolution and abnormal shaped ovarian follicles .2. high content of fibroblasts filled the section .3 inflammatory cells surrounded the dissolved follicles (X 200).

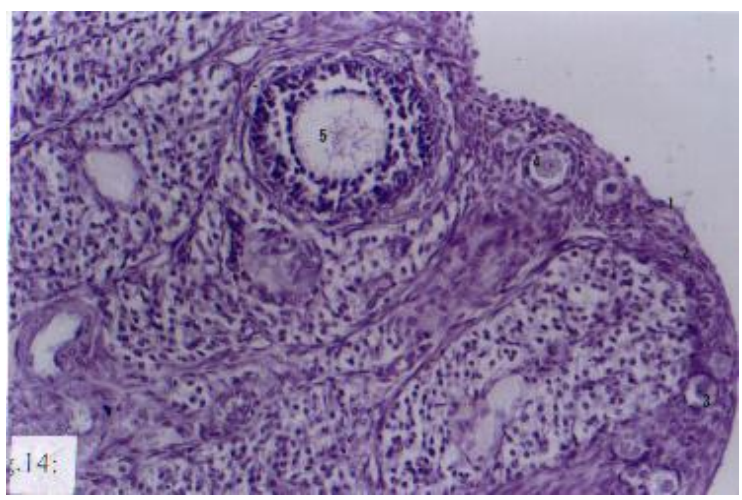

Fig.14: Photomicrograph of a section in the ovary of Evening Primrose Oil treated rats after $24 \mathrm{hrs}$ post irradiation showing 1 . well-defined germinal epithelium, 2. normal tunica albuginea. 3. normal perimordial follicles. 4. normal primary follicles. 5.will-defined corpus luteum with normal granulosa cells and thecal cells (X200). 


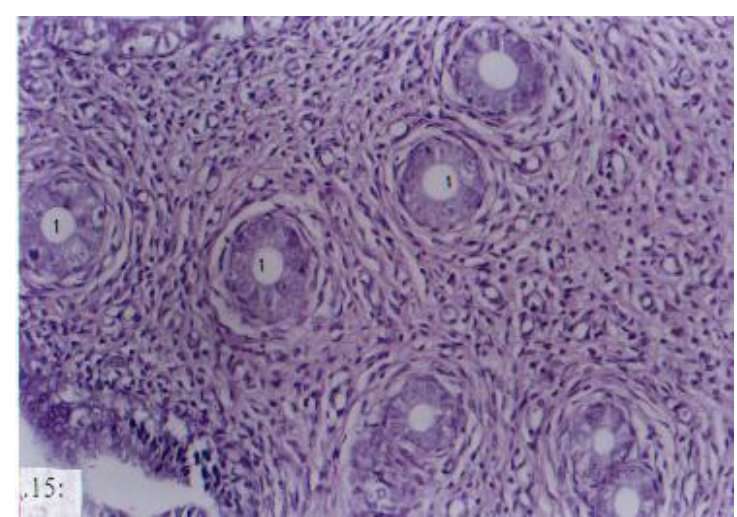

Fig.15: Photomicrograph of a section in the ovary of Evening Primrose Oil treated rats after 6 days of irradiation showing 1. regeneration of different stages of ovarian follicles (X 200)

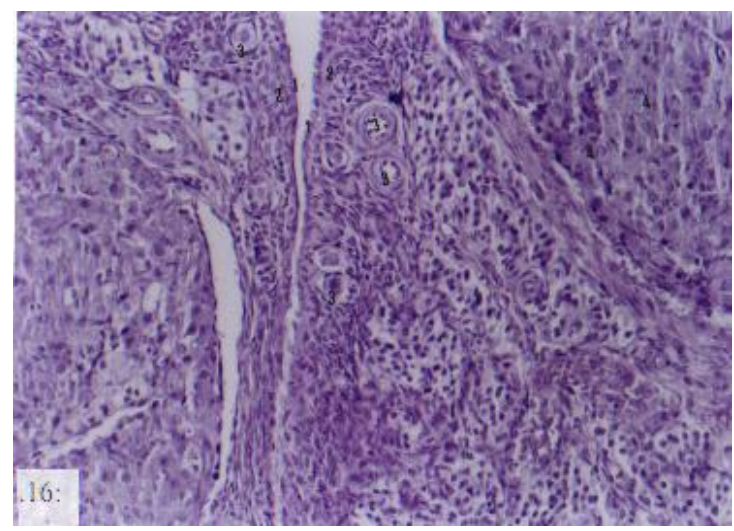

Fig.16: Photomicrograph of a section in the ovary of Evening Primrose Oil treated rats 12 days post irradiation showing 1. normal germinal epithelium. 2. normal tunica albuginea .3. regeneration of perimordial and primary ovarian follicles. 4. well-defined shaped corpus luteum with granulosa cells and theca cells (X 200).

\section{Discussion}

Exposure to ionizing radiation is characterized by excessive production of reactive oxygen species (ROS) associated with inflammatory process (Beyzadeoglu et al., 1997).

The results obtained in the present study showed that whole body exposure of rats to $\gamma$-irradiation resulted into significant drop in RBC's, WBC's and haemoglobin concentration, significant increase in the level of total cholesterol, significant decrease in calcium level, significant increase in plasma urea and creatinine level and significant elevation in serum FSH and
LH. Histological abnormalities in the kidney and ovary tissues were also observed in irradiated rats.

Evening primrose oil administered pre-irradiation, ameliorated the disturbance, in the parameters under investigation.

In this work, the significant decrease in haemoglobin concentration recorded in irradiated rats could be related to a decrease in haemoglobin affinity for oxygen (Saad El-Deen et al., 1996), atrophy of bone marrow and destruction of RBC's (Abu-Seif et al., 2003).

The decline in total leucocytic count (T.L.C.) might be due to change in lymphocytes and neutrophils count (Roushdy \& Ashry, 1979 and Fekry et al., 1999), as well as mitotic changes ; lymphocytes share with the oocytes the property that they die in the interphase after irradiation (Abou-Safi et al., 1999).

Administration of EPO prior to irradiation induced a significant amelioration of these changes, which might be attributed to the presence of (GLA) n-3 and (LA) n-6. Stone et al., (1979) reported that EPO minimizes antithrombotic changes and increase the capacity of platelets to synthesize prostaglandin $\mathrm{E}_{1}\left(\mathrm{PGE}_{1}\right)$, Urakaz et al., (1987) explained that n-3 fatty acid supplementation increases platelets and red blood cells counts 5 times due to its effect on platelets aggregation and fatty acids composition in platelets and red blood cell membranes (De La Cruz et al., 1997).

Furthermore, EPO has an inhibitory effect on cyclooxygenase activity and increase arachidonic acid in erythrocytes membranes (Corbett et al., 1991).

The significant elevation in plasma total cholesterol content might be due to the stimulation of cholesterol synthesis in the liver after 10-40 $\mathrm{min}$ of radiation (Kaznacheev et al., 1985). Moreover, Iiling worth et al., 1995 contributed that irradiation induced increased number of low density lipoprotein (LDL). Also Cerin et al., 1993 showed that cholesterol which was higher in the follicular phase in women with premenstrual syndrome. The high level of cholesterol in irradiated rats that were accompained by significant amelioration in cholesterol level observed in EPO 
treated irradiated rats might be due to the presence of (GLA) n-3 and (LA) n-6 of EPO that inhibit the increasing of plasma total cholesterol (Fukushima et al., 1997).

In this work, whole body $\gamma$-irradiation of $\mathrm{Ca}++$ rats $(5 \mathrm{~Gy})$ resulted into a significant decrease in plasma calcium level that might due to $\mathrm{Ca}$ ions activation by absorbed radiation energy and $(\mathrm{Ca})$ reaction with free radicals. Furthermore, hypocalcemia might be due to increase in renal calcium excretion. The results obtained showed that a high level of cholesterol content was accompanied by a low level of calcium.

This correlate with the vice versa relation of calcium and cholesterol (Garland et al., 1997).

In the present study, the increased level of plasma urea and creatinine after irradiation reflected renal damage. This elevation might be related to slight increase in tissue hydration at the estrus stage (Abou-Safi, 1998), also associated with increased estrogen level in blood and adrenal croticosteroids showed heterogenous sensitivity to irradiation and may also result from reduction in effective renal plasma flow and glomerular filteration rate (Robbins et al., 1989 and Robbins et al., 1991).

Pathologic changes in endothelial cells of the renal microvosc- ulature, tubules and glomeruli degeneration were seen after exposure to radiation (Yaes, 1992). The vital role played by the proximal and distal convulated tubules in selective reabsorption of $\mathrm{Na}, \mathrm{Ch}, \mathrm{Ph}, \mathrm{Ca}$, amonia, creatinine and para-amino hippuric acid is injured. This may be due to after exposure radiation subchronic changes as intimal necrosis, subendothelial fibrinoid thrombosis, atrophy of tubules and replacement of collagen (Mettler \& Moseley, 1985).

In the present study, sections of the kidney tissue of irradiated rats showed loss of normal renal cortex with loss in corpuscle structure, widened, dilated, atrophy and ruptured proximal and distal covulated tubules, ill-defined glomerulai, haemorrhage, inflammatory cells and fibroblasts in the glomerulai surrounding and filling it.

The results obtained from the present study depicted that the protection with EPO pre irradiation played an effective role in improving disorders induced by irradiation. Barcelli et al., 1986, found that EPO and other polyunsaturated fatty acids when fed to partially nephrectomized rats have favorable effects on the progression of renal failure. The author found that changes induced in platelets production of thromboxane $\mathrm{A}_{2}$ and the renal production of various eicosanoids act as protective role of oils.

The protective role of EPO migh be mediated by its efficiency to minimize nephrotoxicity (Darlametsos and Varonos, 2001).

EPO reduces inflammation and caused a significant rise in the amount of dihomogammalionlenic acid in plasma phospholipid fatty acids (schalin-Karrila et al., 1987). Also dietary EPO offset nephrotoxic effects and may be useful in minimizing hypertension (Mills et al., 1992).

Furthermore, diet prepared with EPO had a clear beneficial effect on glomerular sclerosis and tubular abnormalities (Barcelli et al., 1990).

In the present study, there was reversible relationship between secretion of gonadotropin and the period of time, where LH level was greater in the follicular phase.

On the contrary, FSH level was greater in the follicular phase than during lutin phase. Also, hypersecretion of Fsh and LH as observed after whole body gamma irradiation might result either from activation of hypothalamic pituitary axis or as a positive feed back mechanism in response to the lowered levels of estradiol and progesteron in serum. Also radiation induced damage of central nervous system may be reflected on hormonal secretion (Saleh et al., 1988).

Administration of EPO before irradiation ameliorates the radiation induced hormonal changes that might be mediated by prostaglandin, which play a role in the pathophysiology of premenstrual syndrome and ovulation. 
This work showed that radiation induced injuries on ovarian tissue in the form of abnormal shape and dissolution of the majority of the follicles and absence of mature follicles. Furthermore, the theca interna and granulosa cells of the ovarian follicles and the corpus luteum had ruptured and ill-defined shaped.

Changes after radiation exposure severly reduces the formation of steriod hormones, even to the point of gonadal failure (Littley et al., 1991 and Wallace et al., 1989). Persistently elevated gonadotropin levels (FSH and LH) and amenorrhea were associated with the reduced ovarian hormones (Littley, et al., 1991). This might be related with injured theca interna and granulosa cell of ovarian follicles Ganong, 1989. Abdominal radiation of females in childhood resulted in pubertal failure or premature menopause (Wallace et al., 1989).

In this work significant protection and amelioration was afforded when animals were supplied EPO pre-irradiation. The ovarian sections showed mature corpus luteum, well-defined shaped granulosa and thecal cells of ovarian follicles.

Essential fatty acids in EPO are found in the structural lipids of the cells, are concerned with the structural integrity of the mitochondrial membrane and occur in high concentration in the reproductive organs (Harper et al., 1979).

Horrobin, 1983 demonstrated that EPO is a highly effective treatment for the depression and irritability, the breast pain and tenderness, and the fluid retention associated with the premenstrual syndrome. Nutrients known to increase the conversion of essential fatty acids to prostaglandin, $\mathrm{E}_{1}$ include magnesium, zinc, niacin and asorbic acid. The clinical success obtained with some of these nutrients may in part be related to their effects on essential fatty acid metabolism.

It could be concluded that EPO rich in essential fatty acids gamma linolenic acid and linoleic acid might play a role in the modulation of radiation-induced biochemical and histological damage.

\section{References:}

1. Abou-Safi, H. M. (1998): Physiological impairment of irradiation drugs estrus cycle in rats and role of combined treatment with vitamins A and B group. Egypt. Med. Sci. 19 (1), 157.

2. Abou-Safi, H. M.; Hussein, A. H. and ElSayed, N. M. (1999): Efficacy of Vitamin $\mathrm{A}$ and / or E as antioxidants against serum glucose, liver glycogen and lipid discrepancy induced by gamma radiation during the estrus cycle of rats. Egypt. J. Rad. Sci. Applic. 12 (2), 51.

3. Abou-Seif, M. A.; El-Naggar, M. M.; ElFar, M.; Ramadan, M. and Salah, N. (2003): Preventation of biochemical changes in gamma irradiated rats by some metal complexes. Clin. Chem. Lab. Med. 41 (7), 926.

4. Allain, C. C.; Poon, L. S.; Chan, C. S. G.; Richmond, W. and FU, P. C. (1974): Enzymatic determination of total serum cholesterol. Clin. Chem. 20 (4), 470.

5. Barcelli, U. O.; Miyata, J.; Ito, Y.; Gallon, L. and Pollakve, U. (1986): Beneficial effects of polyunsaturated fatty acids in partially Nephrectomized rats. Prostaglandins 32 (2), 211.

6. Barcelli, U. O.; Weiss, M.; Beach, D.; Motz, A.; Thompson, B. (1990): High linoleic acid diets ameliorate diabetic nephropathy in rats. Am. J. Kidney Dis. 16 (3), 244.

7. Beyzadeoglu, M.; Balkan, M.; Demiriz, M.; Birican, B. (1997): Protective effect of Vitamin A on acute radiation injury in the small intestine. Rad. Med. 15 (1), 1.

8. Cerin, A.; Collins, A.; Landgren, B. M. and Eneroth, P. E. (1993): Hormonal and biochemical profiles of premenstrual syndrome. Treatment with essential fatty acids. Acta Obstet. Gynecal. Scand 72 (5), 337.

9. Cockerham, L. G.; Mickly, G. A.; Walden, T. L.; Jr. and Stuart B. O. (1994): Ionizing radiation In: Principles and Methods of toxicology. $3^{\text {rd }}$. Ed. By A. Wallace Hayes. Raven press, Ltd. New York. Ch. 13 p. 456.

10. Corbett, R.; Menez, J. F.; Floch, H. H. and Leonard, B. E. (1991): The effect of chronic Ethanol administration on rat liver and erythrocyte lipid composition modulatory role of Evening Primrose oil. Alcohol 26 (4), 459. 
11. Dacie, J. V. and Lewis, M. S. (1993): Practical haematology $6^{\text {th }}$ Ed., Ch.5 churchill livingstone, London and New York. 37.

12. Darlametsos, I. E. and Varonos, D. D. (2001): Role of prostanoids and endothelins in the prevention of cyclosporin-induced nephrotoxicity. Prostaglindins Leukot. Essent. Fatty Acids 64 (4-5), 231.

13. De La cruz, J. P.; Martin-Romero, M.; Carmona, J. A.; Villalobos, M. A. and Se La cuesta, F. (1997): Effect of Evening Primrose oil on Platelets aggregation in rabbits an atherogenic diet. Thromb. Res. 87 (1), 141.

14. Fekry, A. E.; Samia, E. and Hegazy, R. A. (1999): Influence of Methandienone on serum protein fractions and some physiological parameters in gamma irradiated rats. Egypt. J. Rad. Sci. Applic. 12 (2), 117.

15. Fukushima, M.; Matsuda, T.; Yamagishi, K.; Nakano, M. (1997): Comparative hypocholesterolemic effects of six dietary oils in cholesterol fed. Rats after long-term feeding. Lipids 32 (10), 1069.

16. Ganong, W. F. (1989): Review of Medical physiology, $14^{\text {th }}$ ed. Appleton and Lange, San Maleo, CA.

17. Garland, H. O.; Forshaw, A. G. and Sibley, C. P. (1997): Dietary essential fatty acid supplementation urinary calcium excretion and reproduction performance in the diabetic pregnant rat. Endocrinol. 153 (3), 357.

18. Graz, R.; Buras, B. J.; Manlimos, F. and Abraharm, G. (1975): Analytical letters 8, 225 cited from saleh (1988).

19. Harper, H. A.; Rodmell, V. W. and Mayes, P. A. (1979): Metabolism of lipids In: Review of physiological chemistry, $17^{\text {th }}$ ed. Middle East Edition, Librairie du Liban, Lange Medical publications. P. 333.

20. Henry, J. B. (1974): Clinical diagnosis and measurement by laboratory methods. Todd. Sanford, Davidsohn, $16^{\text {th }}$ ed. W. B. Saunders. Philadelphia, P. A. P. 260.

21. Horrobin, D. F. (1983): The role of essential fatty acids and in the premenstrual syndrome. J. Reprod. Med. 28 (7), 465.

22. Illingworth, D. R.; Duell, P. B. and Connor, W. E. (1995): Disorders of lipid metabolism. Edit by Felig, P.; Baxter, S. D. and Forhman, L. A. $3^{\text {rd }}$ Internation. Edition Mc Crow-Hill, Inc. 1315.

23. Kaznacheev, Y. U. S.; Kulagina, T. P.; Markovich, L. N. and Kalonytseva, I. K.
(1983): Radiation induced changes in lipid content of liver and thymus chromation of gamma irradiation rats Radiobiol. 25 (2), 174.

24. Littley, M. D.; Shalet, S. M. and Beardwell, C. G. (1991): Radiation and the hypothalamic-pituitary axis In: Radiation injury to the nervous system, edited by $\mathrm{P}$. H. Gutin, S. A. Leibel, and G. E. Sheline, P. 303 Raven press, New York.

25. Mahesh, V. B. and Brann, D. W. (1992): Interaction between ovarian and adrenal steriods in the regulation of gonadotropin secretion. J. Steroid. Biochem. Molec. Biol. 41 (3-8), 495.

26. Mettler, F. A.; Jr. and Moseley, R. D.; Jr. (1985): Medical effects of ionizing radiation. Grune and stratton, New York.

27. Mills, D. E.; Ward, R. P.; Me Cutcheon, D.; Dixon, H.; Ly, H. and Scholey, J. (1992): Attenuation of cyclosporineinduced hypertension by dietary fatty acids in the borderline hypertensive rat. Transplantation 53 (3), 649.

28. Monroy, R. L. (1987): Radiation effects on the lymphohematopoietic system: Compromise in immune competency In: Military Radiobiology, edited by J. J. conklin and R. I. walker, 113, Academic Press, San Diego.

29. Robertson, J. B. (1989): Toxicology of ionizing radiation In: A Guide to general toxicology, $2^{\text {nd }}$ ed., edited by J. K. Marquis, P. 141. S. Karger A. G., New York.

30. Robbins, M. E.; Campling, D.; Rezvani, M.; Golding, S. J. and Hopewell, J. W. (1989): Radiation nephropathy in mature pigs following the irradiation of both kidneys. Int. J. Radiat. Biol. 56, 83.

31. Robbins, M. E.; Bymaters, T.; Rezvani, M.; Colding, S. T. and Hopewell, J. W. (1991): Residual radiation-induced damage to the kidney of the pig as assayed by retreatment. Int. J. radiat. Biol. 60, 917.

32. Roushdy, H. M. and Ashry, M. A. (1979): Haematopoitic response to the interaction between protein malnutrition and gamma irradiation Isotope and Radiat. Res. 11.

33. Saad El-Deen, A.; Abdel-Fattah, K. T. and Roushdy, H. M. (1996): IR spectral modification of gamma irradiated haemoglobin of rat and prophylactic role of immidazole. J. Egypt. Ger. Soc. Zool. 21 (A) conf. Physol., 203.

34. Saleh, S.; Roushdy, H. M.; Abde Aziz, M. T. and Ramadan, L. A. (1988): Radiationinduced disorders in ovarian function. Egypt. J. Rad. Sci. Applic. 5 (1), 75. 
Fatma, L.R. \& and Rezk R. G.

35. Schalin-Karrila, M.; Mattila, L.; Tansen, C. T. and Uotila, P. (1987): Evening primrose oil in the treatment of atopic eczema: Effect clinical status, plasma phospholipid fatty acids and circulating prostaglandins. Br. J. Dermatol. 117 (1), 11.

36. Senedecor, G. W. and Cochran, W, G. (1978): Statistical methods $8^{\text {th }}$ ed., Univ.Press, USA.

37. Stem, J. and Lewis, W. H. P. (1957): Clin. Chem. Acta. 2, 576. Cited from saleh (1988).

38. Stone, K. J.; Willis, A. L.; Hart, W. M. and Kernoff, P. B. (1979): The metabolism of dihomo-gamma-linolenic acid in man. Lipid 14 (2), 174.

39. Urakaze, M.; Hamazaki, T.; Hakuta, M.; Ibuki, F.; Yano, S. and Kumagai, A. (1987): Effect on platelet aggregation and fatty acid composition in phospholipids of plasma. platelets, and red blood cell membranes in rabbits. Am. J. Clin. Nutr. 46 (6), 936.

40. Walden, T. L.; Jr. and Farzaneh, N. K. (1990): Biochemistry of Ionizing Radiation Raven. Press, New York.

41. Wallace, W. H.; Shalet, S. M.; Crowne, E. C.; Morris. Jones, P. H. and Gattamaneni, H. R. (1989): Ovarian failure following abdominal irradiation in childhood: natural history and prognosis. Clin. Oncol. (R. Coll. Radiiol.) 1, 75.

42. Yaes, R. J. (1992): Radiation damage to the kidney. In: Advances in Radiation Biology, Vol. 15. Relative Radiation sensitivities of Human organ systems, Parrts III, edited by K. I. Altman and J. T Lett, P. 1-35 Academic Press, San diego. 


\title{
استخدام زيت البريمروز فى الحد من بعض الاختلالات الوظيفية والتركيبية التى يحدثها فى إناث الجرذان الانئ
}

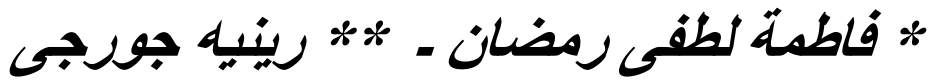 \\ *قسم البيولوجيا الإشعاعية ـ **قسم البحوث الصحية الإشعاعية

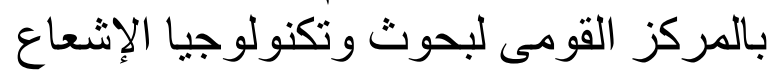

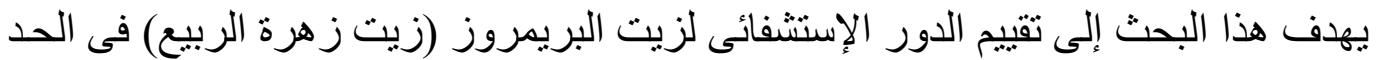

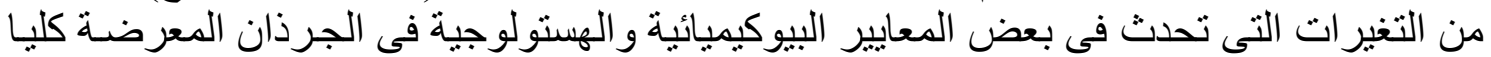

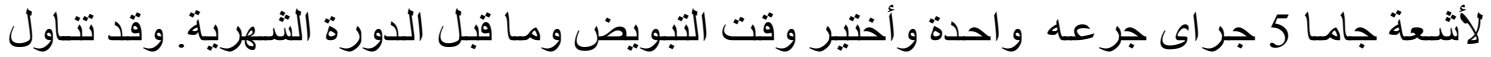

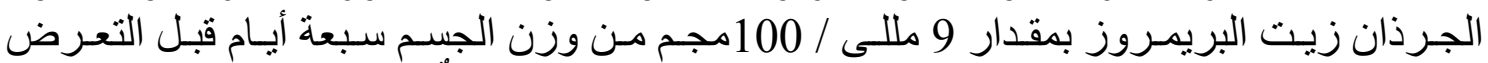

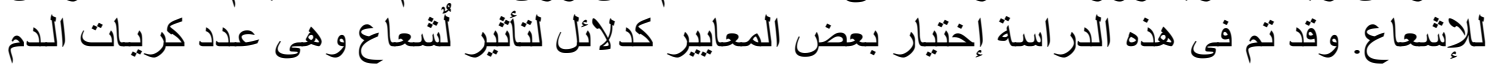

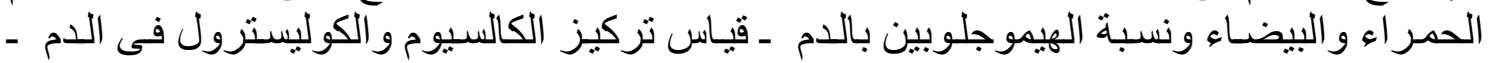

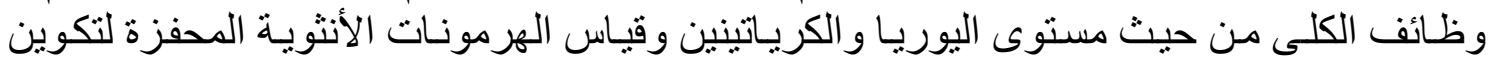

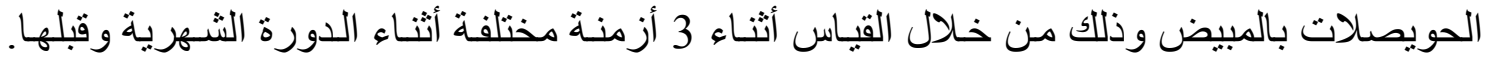
ذلك بالإضافة إلى إجر اء الفحص النسيجى لخلايا الكلى و المبيض.

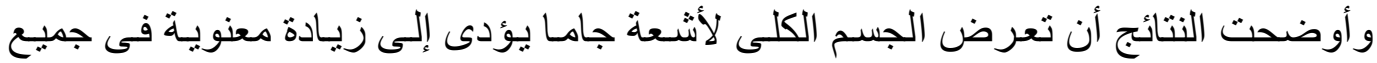

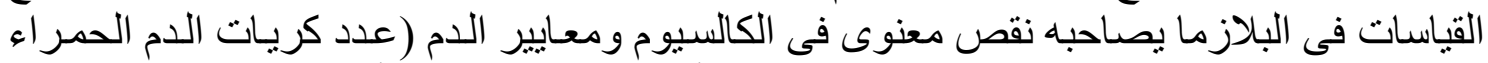

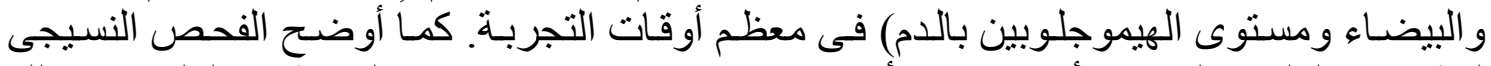

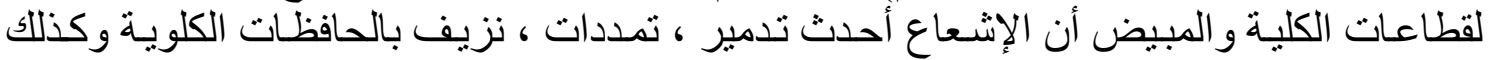

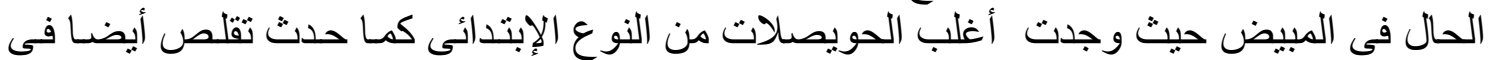

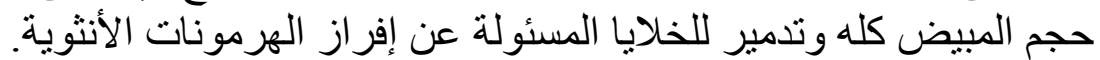

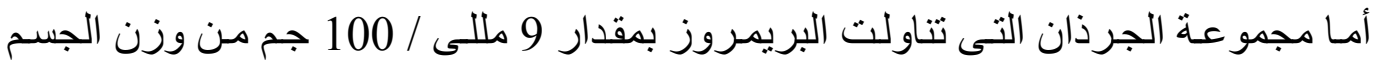

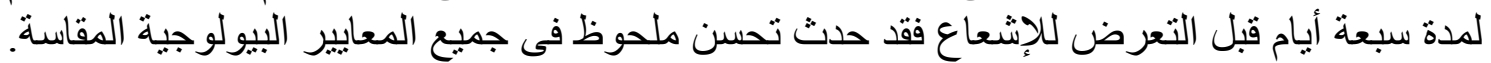

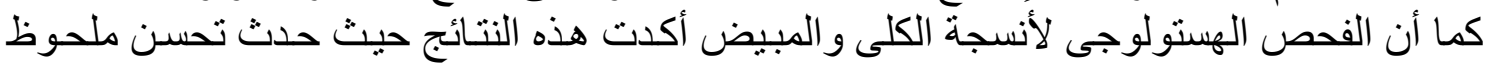

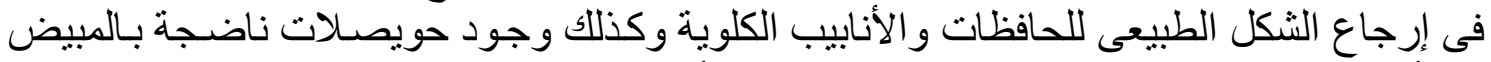

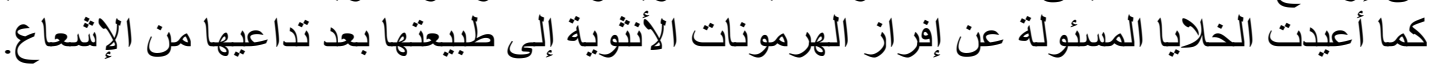

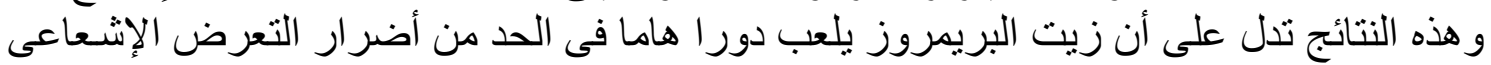

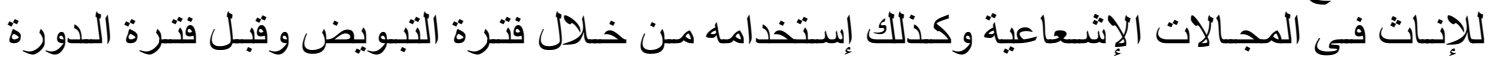
الشهرية للتخفيف من آلاني المها. 